\title{
DEVELOPMENT CONCEPT IN EAST BALIKPAPAN WITH MINAPOLITAN APPROACH
}

\author{
Tiara Irawanti*, Eko Budi Santoso**, Haryo Sulistyarso** \\ *) Master Student, Department of Architecture, Institute of Technology Sepuluh \\ Nopember, Indonesia \\ **) Department of Architecture, Institute of Technology Sepuluh Nopember, Indo- \\ nesia \\ e-mail: tiaraiyra@gmail.com
}

\begin{abstract}
East Balikpapan district is the largest fish producer in Balikpapan City. The magnitude of the potential of the fishery is due to waters of East Balikpapan directly opposite to the Makassar Strait. But the magnitude of the fisheries's potency sector in East Balikpapan cannot provide added value to the development of the area yet. When compared with 4 (four) other districts in Balikpapan city, construction on the eastern seaboard of Balikpapan is less developed and less attention impressed. Therefore, the purpose of this study is to develop East Balikpapan by optimizing fisheries resources or referred to minapolitan.

This study used four analyses. Growth and share method is used to identify the leading commodities in fisheries sector. Descriptive analysis is used to identify the production chain of fisheries. Correlation and regression analysis is used to find the factors that influence the development of minapolitan. To arrange the concept of development is using descriptive analysis.

The factors that influence the development of Minapolitan in East Balikpapan divided into six factors. Those factors are: fishermen income; linkages between sectors; the production of fisheries; capital; mode of transport; and accessibility. The concept of development which can be made starting from upstream subsystem, downstream subsystem, and supporting subsystem.
\end{abstract}

Keywords: fisheries, regional development, minapolitan

\section{INTRODUCTION}

Coastal areas have huge potential in the development of the region, both renewable resources and not renewable resources. During these fishing activities which are generally located in rural areas, has a slow growth area, due to lack of facilities, infrastructure and public service facilities. Rural areas more of a role as providers of raw materials, while the value-added production is more enjoyed in urban areas. 
The development of coastal areas can be pursued through an approach that is minapolitan. Minapolitan is an effort to develop the area with fishing activities as primary activities (Ministry of Maritime and Fisheries, 2011). Minapolitan concept aims to: First, increase production, productivity, and quality of marine and fishery products. Second, increase the income of fishermen, fish farmers and fish processors are fair and equitable. Third, Minapolitan as a center of economic growth in the surrounding area (Decree No. 18 of the General Guidelines Minapolitan, 2011).

Balikpapan city has approximately $337.80 \mathrm{~km}^{2}$ of sea area with a length of $45.60 \mathrm{~km}$ beach or approximately 67 percent of the land area and holds the potential of coastal and marine resources are quite large and diverse. Balikpapan City is the largest producer of fish in the province of East Kalimantan with the production 12,986 ton/year (Adnan, 2010). That is indicates that Balikpapan city has a great potential in the fisheries and marine sector.

Eastern region of Balikpapan city is the one of the largest fish producer in the Balikpapan city. It is seen from fisheries production in East Balikpapan in 2013 reached 3,816 tons or 72 percent of total fisheries production in Balikpapan (Department of Agriculture, Fisheries, and Marine Balikpapan City, 2014). But the magnitude of the potential of the fisheries sector in East Balikpapan is not used optimally. It is seen from the results of fisheries not already have economic value added. The production of fish is directly marketed without being processed, so the benefits of the fisheries sector is not the maximum (Suharto, 2012).

Exploiting the potential of the fisheries sector is also not optimal impact on development in coastal areas of East Balikpapan. The location is far from the city center cause to infrastructure and facilities in these districts is inadequate, and the quality of human resources is also relatively low compared with the human resources in the city center. Approximately 47 percent of all roads in East Balikpapan still a dirt road. Besides that, some people are still using wells dug even river water as a source of clean water, 45 percent of new households have been using PDAM (District of East Balikpapan in Figures, 2013). Therefore, need an integrated concept to develop the East Balikpapan by optimizing the fisheries sector. Thereby can increasing the resources of communities, reducing the disadvantaged areas and to minimize disparities between regions.

\section{THEORY AND RESEARCH METHODS}

Based on the theory of regional development from Hoover (1977), a regional development need to consider the socio-cultural, economic, physical environment, and institutional aspects. It was agreed with Friedman (1976) that in order to realize the regional development need the economic aspects, socio-cultural, and the environment. For the development minapolitan, Dahuri (2001), and Ghufron (2008) argues that human resources, infrastructure and facilities, institutional, technology and information, and marketing is an indicator that affects the development of minapolitan.

Then the indicators used in this study include human resources, infrastructure and facilities, institutional, and information technology, and 
marketing. While the variables used are level of skill; the needs of society; the quality of employment; communities income; fisheries production; operating costs; marketing; selling price stability; linkage between sectors; capital; mode of transportation; accessibility; water network; availability of fish port; group of fishermen; and role of government.

\section{Research Methods}

This type of research is descriptive quantitative and qualitative methods. Quantitative methods are used to determine the leading commodity of fisheries in East Balikpapan, analyze the factors that influence the development related Minapolitan in East Balikpapan. While the qualitative methods used to analyze the fisheries production chain and to arrage the development concept. Based on a literature review, the research indicators are: human resources; economic; infrastructure and facilities; institutional; technology and information.

The population in this study is a fishermen in Manggar and Manggar Baru kelurahan or village in East Balikpapan, with the determination of the total sample of respondents each village were divided proportionally so that the data obtained balanced. Methods of data collection is done by the method of observation, questionnaire, agencies survey, and literature. The analytical method used are to determine leading commodity fisheries in the East Balikpapan with growth and share method, descriptive analysis to determine the fishing production chain, correlation and regression analysis to obtain the factors that influence the development minapolitan, and descriptive analysis to arrange regional development concept with minapolitan approaches.

\section{RESULTS AND DISCUSSION}

East Balikpapan sub-district has an area of $132.16 \mathrm{~km}^{2}$, or approximately 26.25 percent of the area of the Balikpapan, which consists of 4 (four) kelurahan or village, are Manggar, Manggar Baru, Teritip, and Lamaru. In this study, the research area is limited to Manggar and Manggar Baru with an area of $39.10 \mathrm{~km}^{2}$. Selection of these two locations because Manggar and Manggar Baru have potential to be developed as Minapolitan region. The total population in the study area in 2013 is 70,737 inhabitants with a population density of 1,249 inhabitants $/ \mathrm{km}^{2}$.

The condition of the road network in the study area is mostly in good condition with the use of asphalt pavement. However there are still some neighborhood streets are still a dirt road, especially those in the fishing settlement.

Electricity network in the area of research has been met with good and accessible to residential areas. And for the clean water network, people use PDAM, well pumps, water streams, and springs as a source of clean water.

The number of households fishery also called in Rumah Tangga Perikanan (RTP) in the East Balikpapan in 2013 as many as 821 RTP or by 66 percent of the total RTP in Balikpapan city. The increasing number of RTP in East Balikpapan from the previous year, amounting to 776 , due to some fishermen who come from 
outside the city and even outside the island took the family to work also as a fisherman in Balikpapan.

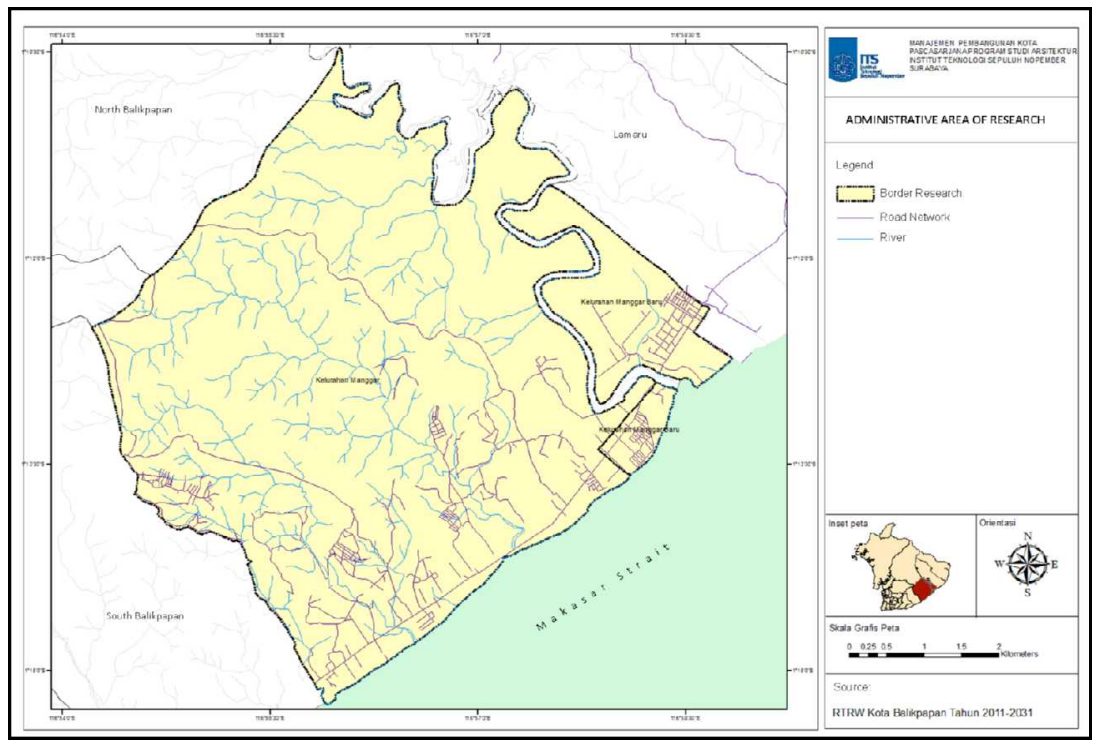

Figure 1.The Administrative Area of Research Source: City Planning Documents of Balikpapan 2011-2031

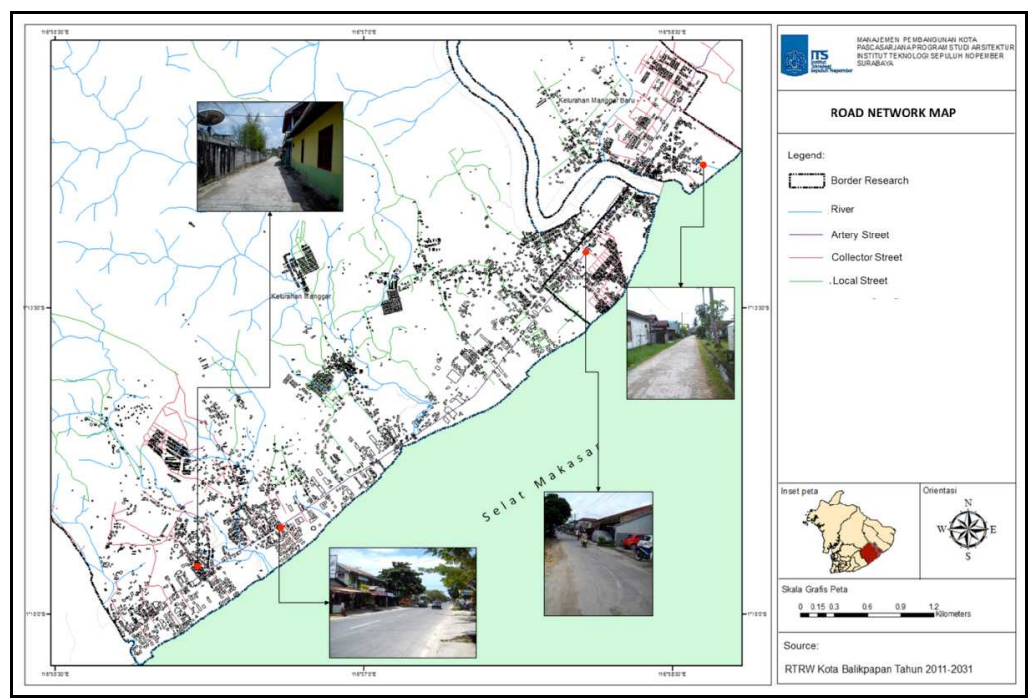

Figure 2.The road network in research area Source: City Planning Documents of Balikpapan 2011-2031, and primary survey, 2015

East Balikpapan has a fishing village. Fishing settlement or commonly referred to as a fishing village located around Fish Landing Base Manggar. Most of the residents are from Bugis and Madura race. For the pattern of settlement, 
settlement of fishermen was formed by spreading and irregular. As for the typology of the building is divided into 2 (two), which is building on water (floating), and building on land.
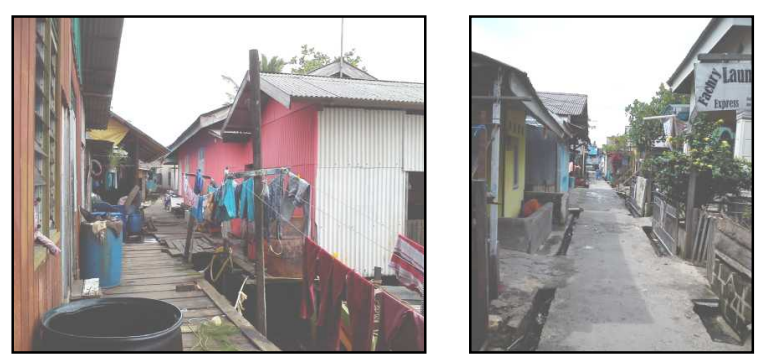

Figure 3. Fishing settlement Source: primary survey, 2015

Supporting facilities of fisheries activities located in the research area is fish landing bases (PPI), and the base station fuel fishermen. PPI is located in Manggar Baru, with a total area of approximately $2.500 \mathrm{~m}^{2}$. PPI is owned by the City Government of Balikpapan through UPT Department of Agriculture, Marine Affairs and Fisheries (DPKP) Balikpapan. PPI Manggar has several facilities, namely dock, fish auction place (TPI), breaking ice blocks, and ice room.

For fisheries production, according to data from the Department of Agriculture, Marine Affairs and Fisheries in Balikpapan, noted that fisheries production in East Balikpapan in 2013 amounted to 3,816.90 tons and reached a value of 55,119,831,000 rupiahs. Fishing tool most used by fishermen East Balikpapan is a type of fishing (DPKP Balikpapan City, 2015). As for the fishing boats used in 2013, consists of a boat without a motor 8 units, and motor boats $<5$ GT as many as 543 units, 5-10 GT as many as 256 units, 10-20 GT as many as 23 units, 20-30 GT 3 units, and >30 GT 2 units.

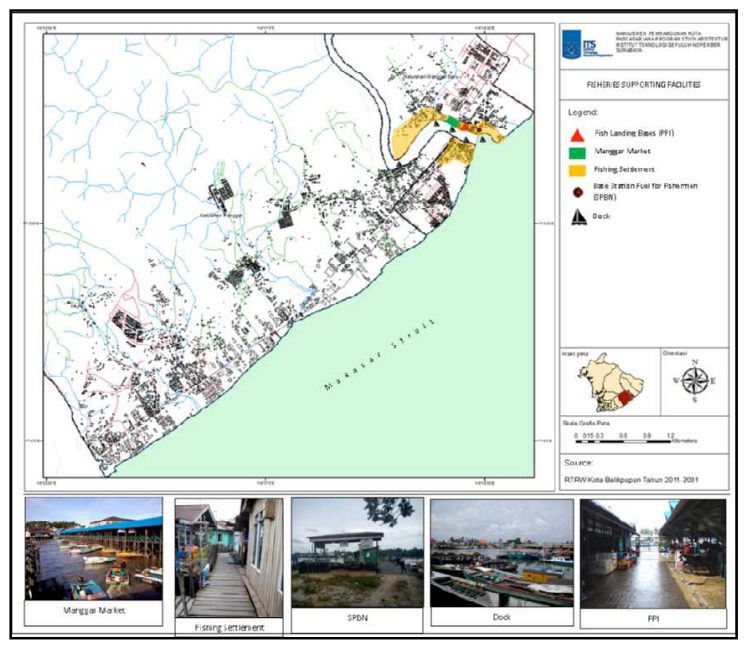

Figure 4. Distribution Map of Fisheries Supporting Facilities Source: City Planning Documents of Balikpapan 2011-2031, and primary survey, 2015 


\section{Identification of Leading Commodities in Fisheries Sector}

In determining the leading commodity of fisheries in East Balikpapan performed with growth and share method.

Table 1. Calculation of Growth of Fisheries Sector in East Balikpapan

\begin{tabular}{|c|c|c|c|c|}
\hline No. & Commodity & $\begin{array}{l}\text { Production in } \\
2013 \text { (ton) }\left(T_{n}\right)\end{array}$ & $\begin{array}{c}\text { Production in } 2010 \\
\text { (ton) }\left(T_{n-1}\right)\end{array}$ & $\begin{array}{c}\text { Growth } \\
(\%)\end{array}$ \\
\hline 1. & Layang & $2,649.30$ & $1.254,90$ & 111,12 \\
\hline 2. & Bawal & 8.50 & 3,60 & 136,11 \\
\hline 3. & Kembung & 92.20 & 39,60 & 132,83 \\
\hline 4. & Selar & 10.70 & 27,60 & $-61,23$ \\
\hline 5. & Tembang & 36,20 & 108,80 & $-66,73$ \\
\hline 6. & Lobster & 1,90 & 0,40 & 375,00 \\
\hline 7. & Windu Shrimp & 4,30 & 1,10 & 290,91 \\
\hline 8. & Jrebung Shrimp & 3,00 & 6,50 & $-53,85$ \\
\hline 9. & Dogol Shrimp & 3,67 & 11,00 & $-66,64$ \\
\hline 10. & Others Shrimp & 2,90 & 2,00 & 45,00 \\
\hline 11. & Teri & 13,40 & 62,40 & $-78,53$ \\
\hline 12. & Tongkol komo & 378,20 & 828,30 & $-54,34$ \\
\hline 13. & Kurisi & 1,50 & 6,80 & $-77,94$ \\
\hline 14. & Lemuru & - & 5,90 & $-100,00$ \\
\hline 15. & Cakalang & 1,70 & 0,10 & $1.600,00$ \\
\hline 16. & Tengiri & 22,10 & 8,20 & 169,51 \\
\hline 17. & Tiga Waja & 0,3 & 0,00 & - \\
\hline 18. & Ekor Kuning & - & 14,20 & $-100,00$ \\
\hline 19. & Trakulu & 22,00 & 8,00 & 175,00 \\
\hline 20. & Peperek & 0,00 & 18,30 & $-100,00$ \\
\hline 21. & Manyung & 3,30 & 4,20 & $-21,43$ \\
\hline 22. & Ketombong & 2,60 & - & - \\
\hline 23. & Cucut & 1,50 & - & - \\
\hline 24. & Pari & 7,90 & 3,60 & 119,44 \\
\hline 25. & White Kakap & 1,40 & 12,20 & $-88,52$ \\
\hline 26. & Sunglir & 0,30 & 0,40 & $-25,00$ \\
\hline 27. & Bambangan & 13,30 & 4,70 & 182,98 \\
\hline 28. & Kerapu & 3,10 & 10,60 & $-70,75$ \\
\hline 29. & Kurau & - & 1,00 & $-100,00$ \\
\hline 30. & Belanak & 0,10 & - & - \\
\hline 31. & Squid & 16,40 & 9,30 & 76,34 \\
\hline 32. & Grey Tongkol & 141,80 & 7,80 & $1.717,95$ \\
\hline 33. & Ketamba & 1,10 & - & - \\
\hline 34. & Alu-alu & 0,70 & - & - \\
\hline 35. & Sembula & 95,50 & - & - \\
\hline 36. & Laso Cina & 10,30 & - & - \\
\hline 37. & $\mathrm{Crab}$ & 37,20 & - & - \\
\hline 38. & Other fishes & 195,10 & 128,40 & 51,95 \\
\hline
\end{tabular}

$$
\text { Growth }=\frac{T_{n}-T_{n-1}}{T_{n-1}} \times 100
$$


Table 2. Calculation of Share of Fisheries Sector in East Balikpapan

\begin{tabular}{|c|c|c|c|c|}
\hline No. & Commodity & $\begin{array}{c}\text { Production Value in } \\
\text { East Balikpapan (NP1) } \\
\text { (in 1,000 rupiahs) }\end{array}$ & $\begin{array}{l}\text { Production Value in } \\
\text { Balikpapan City (NP2) } \\
\text { (in 1,000 rupiahs) }\end{array}$ & $\begin{array}{c}\text { Share } \\
(\%)\end{array}$ \\
\hline 1. & Layang & $42,388,800$ & $57,406,400$ & 73.84 \\
\hline 2. & Bawal & 270,300 & 387,960 & 69.67 \\
\hline 3. & Kembung & $2,083,720$ & $2,266,780$ & 91.92 \\
\hline 4. & Selar & 75,970 & 110,760 & 68.59 \\
\hline 5. & Tembang & 217,200 & 235,200 & 92.35 \\
\hline 6. & Lobster & 340,100 & $1,575,200$ & 21.59 \\
\hline 7. & Windu Shrimp & 487,190 & $2,050,730$ & 23.76 \\
\hline 8. & Jrebung Shrimp & 148,800 & 243,040 & 61.22 \\
\hline 9. & Dogol Shrimp & 114,871 & $1,718,370$ & 6.68 \\
\hline 10. & Others Shrimp & 14,500 & 16,000 & 90.63 \\
\hline 11. & Teri & 93,800 & 98,700 & 95.04 \\
\hline 12. & Tongkol komo & $5,219,160$ & $6,971,760$ & 74.86 \\
\hline 13. & Kurisi & 14,250 & 18,050 & 78.95 \\
\hline 15. & Cakalang & 17,000 & 17,000 & 100.00 \\
\hline 16. & Tengiri & 669,630 & 705,990 & 94.85 \\
\hline 17. & Tiga Waja & 1,410 & 1,880 & 75.00 \\
\hline 19. & Trakulu & 624,800 & 900,280 & 69.40 \\
\hline 21. & Manyung & 26,730 & 36,450 & 73.33 \\
\hline 22. & Ketombong & 46,800 & 66,600 & 70.27 \\
\hline 23. & Cucut & 13,500 & 15,300 & 88.24 \\
\hline 24. & Pari & 55,300 & 61,600 & 89.77 \\
\hline 25. & White Kakap & 49,700 & 74,550 & 66.67 \\
\hline 26. & Sunglir & 10,500 & 10,500 & 100.00 \\
\hline 27. & Bambangan & 585,200 & $1,562,000$ & 37.46 \\
\hline 28. & Kerapu & 126,480 & 171,360 & 73.81 \\
\hline 30. & Belanak & 630 & 1,260 & 50.00 \\
\hline 31. & Squid & 569,080 & 621,130 & 91.62 \\
\hline 32. & Grey Tongkol & $2,353,880$ & $2,594,580$ & 90.72 \\
\hline 33. & Ketamba & 26,400 & 33,600 & 78.57 \\
\hline 34. & Alu-alu & 6,440 & 6,440 & 100.00 \\
\hline 35. & Sembula & 630,300 & 972,840 & 64.79 \\
\hline 36. & Laso Cina & 51,500 & 99,500 & 51.76 \\
\hline 37. & Crab & 758,880 & $1,122,000$ & 67.64 \\
\hline 38. & Lainnya & $2,653,360$ & $4,992,560$ & 53.15 \\
\hline Total & & $55,119,831$ & $82,691,822$ & 66.66 \\
\hline
\end{tabular}

Share $=\frac{\mathrm{NP} 1_{\mathrm{n}}}{\mathrm{NP} 2_{\mathrm{n}}} \times 100$ 
Based on the analysis of growth and share, obtained the commodity becomes the leading commodity, potentially commodity, dominant commodity, and static commodity in East Balikpapan. For commodities which have growth $(+)$ and share-value $>50$ percent, then set as the leading commodity, and being in the right upper quadrant. For commodities which have growth $(+)$ and share-value $<50$ percent, then set as the dominant commodity, and is located in the upper left quadrant. As for commodities which have growth (-) and share-value $>50$ percent, then the commodity is a potential commodity, and is in the lower right quadrant. For commodities has growth (-) and share-value $<50$ percent, then the commodity is a static commodity, and is located in the lower left quadrant.

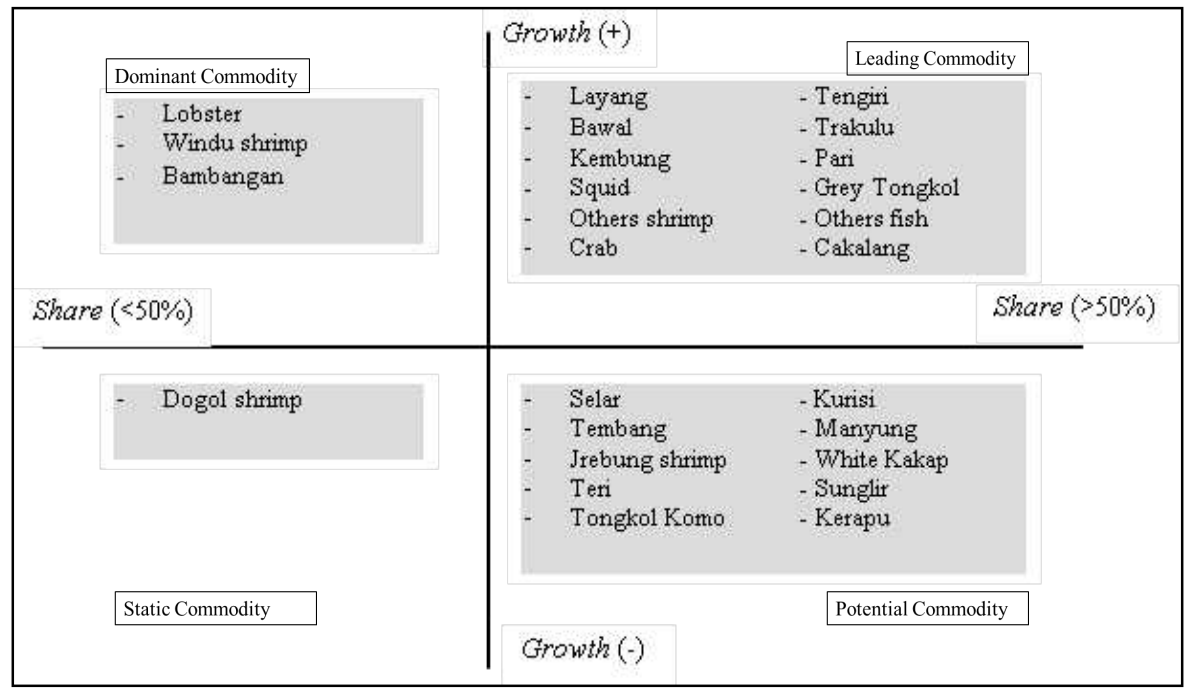

Figure 5. Growth and Share Quadrant of Commodities Fishing in East Balikpapan Source: writer, 2015

\section{Production Chain Analysis of Leading Commodities}

Production chain is an activity or activities ranging from raw materials and processing to sales or marketing.

Table 3. Production Quantities of Leading Commodities are Consumed Fresh

\begin{tabular}{lccc}
\hline \multicolumn{1}{c}{ Commodity } & Production (ton) & Consumed Fresh (ton) & Percentage (\%) \\
\hline Layang & $2,649.30$ & $2,384.36$ & 89.99 \\
Bawal & 8.50 & 8.50 & 100.00 \\
Kembung & 92.20 & 87.60 & 95.01 \\
Squid & 16.40 & 16.40 & 100.00 \\
Others shrimp & 2.90 & 0.54 & 18.62 \\
Crab & 37.20 & 28.11 & 76.39 \\
Tengiri & 22.10 & 19.91 & 90.09 \\
Trakulu & 22.00 & 19.78 & 89.91 \\
Pari & 7.90 & - & 0.00
\end{tabular}




\begin{tabular}{lccc}
\hline \multicolumn{1}{c}{ Commodity } & Production (ton) & Consumed Fresh (ton) & Percentage (\%) \\
\hline Grey Tongkol & 141.80 & 134.72 & 95.00 \\
Others fish & 195.10 & 39.01 & 19.99 \\
Cakalang & 1.70 & 1.60 & 94.12 \\
Total & $\mathbf{3 , 1 9 7 . 1 0}$ & $\mathbf{2 , 7 4 0 . 5 3}$ & $\mathbf{8 5 . 7 2}$ \\
\hline
\end{tabular}

Source: processed from DPKP Balikpapan, 2015

Seen from the table above, amounting to 86 percent of the leading commodity sold fresh without any processing beforehand. While processing that can provide added value for the commodity is only 14 percent. The processing of leading commodities in East Balikpapan, among others, freezing, salting, pemindangan, fogging, and others processing (amplang, fish stick, jerk meat, abon).

Table 4. Fish Processing of Leading Commodity in East Balikpapan in 2013

\begin{tabular}{|c|c|c|c|c|}
\hline No. & Processing & Production (ton) & Percentage (\%) & Commodity \\
\hline 1. & Freezing & 9.09 & 1.99 & crab \\
\hline 2. & Salting & 347.39 & 76.09 & $\begin{array}{l}\text { layang, kembung, others } \\
\text { shrimp, tengiri, trakulu, } \\
\text { pari, grey tongkol, caka- } \\
\text { lang, others fish }\end{array}$ \\
\hline \multirow[t]{3}{*}{3.} & Pemindangan & & & \\
\hline & Presto & 1.74 & 0.38 & \\
\hline & $\begin{array}{l}\text { Pepes } \\
\text { Steam }\end{array}$ & 6.40 & 1.40 & $\begin{array}{l}\text { layang, kembung, crab } \\
\text { crab }\end{array}$ \\
\hline 4. & Fogging & 8.00 & 1.75 & pari, cakalang \\
\hline \multirow[t]{5}{*}{5.} & Others processing & & & \\
\hline & Amplang/crackers & 64.25 & 14.07 & Tenggiri, crab, other fish \\
\hline & Fish stick & 19.55 & 4.28 & crab, other fish \\
\hline & Jerk meat & 0.06 & 0.01 & crab \\
\hline & Abon & 0.09 & 0.02 & crab \\
\hline Total & & 456.57 & 100 & \\
\hline
\end{tabular}
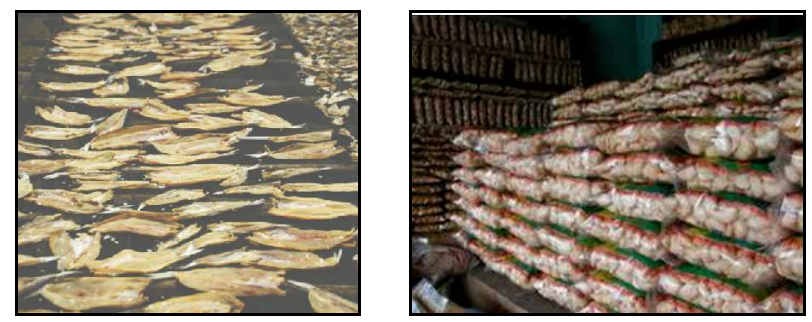

Figure 6. Fish Processing of Leading Commodity 
Source: primary survey, 2015

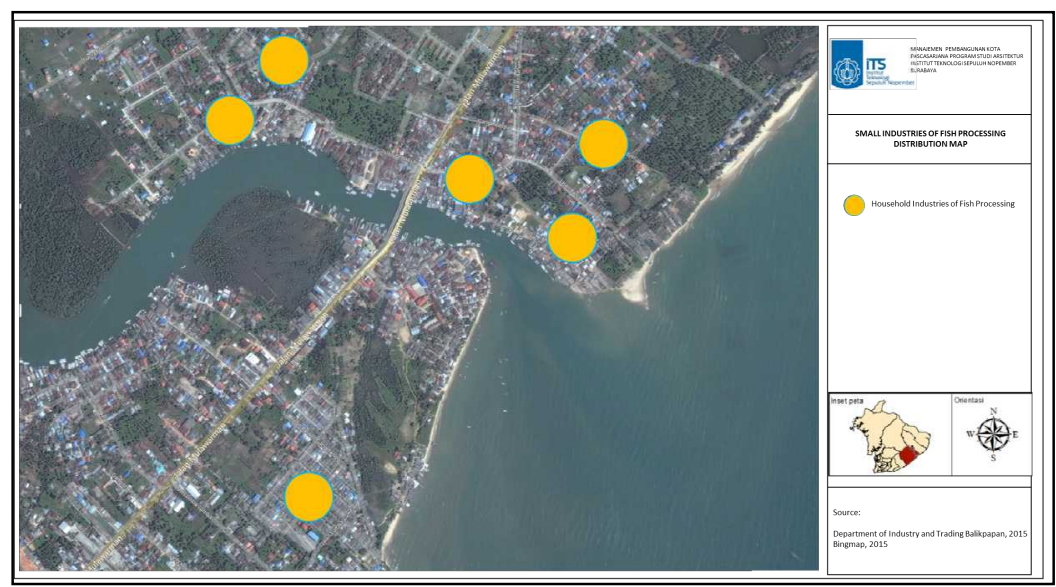

Figure 7. Distribution of fish processing small industries Source: bingmap and Department of industry and trading Balikpapan, 2015

For marketing of leading commodities of East Balikpapan done at local, regional, and export.

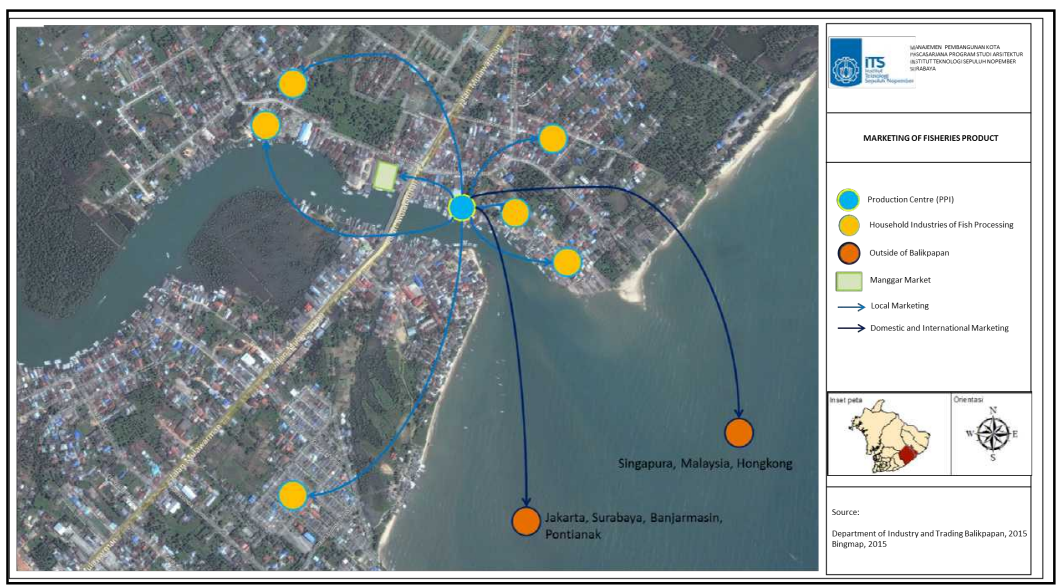

Figure 8. Marketing of leading commodity product

Source: bingmap and Department of industry and trading Balikpapan, and primary survey, 2015

\section{Analysis Factors that Influencing the Development Minapolitan Based on Fisheries in East Balikpapan}

To determine the factors that influence the development of Minapolitan in East Balikpapan is using regression analysis. Prior to the regression analysis, first tested the validity and reliability of the study variables. 
Table 5. The Results of Validity Test

\begin{tabular}{clcccc}
\hline No & \multicolumn{1}{c}{ Variable } & $\begin{array}{c}\text { Value of } \\
\mathbf{r}_{\text {count }}\end{array}$ & $\begin{array}{c}\text { Value of } \\
\mathbf{r}_{\text {table }}\end{array}$ & Sig. & Conclusion \\
\hline 1. & Education level & 0.255 & & 0.012 & Valid \\
2. & Skill level & 0.234 & & 0.022 & Valid \\
3. & Icome & 0.211 & & 0.039 & Valid \\
4. & The needs of society & -0.104 & & 0.313 & Not Valid \\
5. & Selection of vehicles & 0.299 & & 0.003 & Valid \\
6. & Production & 0.224 & & 0.028 & Valid \\
7. & Marketing & 0.103 & & 0.318 & Not Valid \\
8. & Selling price stability & 0.092 & 0.202 & 0.374 & Not Valid \\
9. & Operational costs & 0.333 & & 0.001 & Valid \\
10. & Capital & 0.303 & & 0.003 & Valid \\
11. & Accessibility & 0.239 & & 0.019 & Valid \\
12. & Water sources & 0.061 & & 0.555 & Not Valid \\
13. & Water quality & -0.106 & & 0.305 & Not Valid \\
14. & Mode of transportation & 0.390 & & 0.000 & Valid \\
15. & Availability of fishing port & 0.347 & & 0.001 & Valid \\
16. & Group of fishermen & 0.081 & & 0.435 & Not Valid \\
17. & Linkage between sectors & 0.217 & & 0.034 & Valid \\
18. & Role of government & 0.431 & & 0.000 & Valid \\
\hline & & Source: writer, 2015 & &
\end{tabular}

The results of validity test showed that the variable the needs of society, marketing, selling price stability, water sources, water quality and group of fishermen are not valid. The sixth variable is not valid because value of $r_{\text {count }}$ less

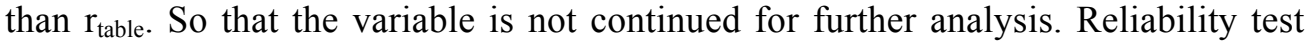
results are based on the value of Cronbach's alpha is 0.753 .

After the validity and reliability test, and then proceed to the stages of correlation and regression analysis (see Table 6 and Table 7).

Table 6. The Results of Correlation Analysis

\begin{tabular}{ll}
\hline \multicolumn{1}{c}{ Dependent Variable } & \multicolumn{1}{c}{ Independent Variable } \\
\hline Income & - Skill level \\
& - Selection of vehicles \\
& - Production \\
& - Operational costs \\
& - Role of government \\
& - Selection of vehicles \\
Linkage between sectors & - Aksesibilitas \\
& - Mode of transportation \\
& - Availability of fishing port \\
& - Role of government \\
\hline
\end{tabular}


Table 7. The Results of Income Regression Analysis

\begin{tabular}{lccc}
\hline Independent Variable & Beta & Sig & Model \\
\hline (constant) & 0.916 & $0.000^{*}$ & \\
Skill level & 0.094 & 0.213 & \\
Selection of vehicle & 0.034 & 0.419 & $\mathrm{Y}=0.916+0.317 \mathrm{X}_{1}+$ \\
Production & 0.317 & $0.001^{*}$ & $0.193 \mathrm{X}_{2}$ \\
Operational costs & 0.021 & 0.563 & \\
Capital & 0.193 & $0.000^{*}$ & \\
Role of government & -0.125 & 0.082 & \\
\hline & \multicolumn{2}{c}{ Source: writer, 2015 }
\end{tabular}

Based on the regression results, which have an influence on people's income are the factors of production, and capital.

1. Production

If fishery production in large amount then the amount of revenues received by the fishing communities will also be increased

2. Capital

During this time the source of fishermen capital mostly from private money. So that each go to fishing, fishermen have to spend its own capital and it affects the income of fishermen.

Table 8. The Results of Linkage between Sectors Regression Analysis

\begin{tabular}{lccc}
\hline \multicolumn{1}{c}{ Independent Variable } & Beta & Sig & Model \\
\hline (constant) & -0.136 & 0.764 & \\
Selection of vehicle & 0.115 & 0.329 & \\
Accessibility & 0.259 & $0.009^{*}$ & \\
Mode of transportation & 0.541 & $0.004^{*}$ & \\
Availability of fishing port & 0.169 & 0.309 & \\
Role of government & -0.124 & 0.494 & \\
\hline & Source: writer, 2015 & \\
\end{tabular}

Based on the regression results, which have an influence on linkage between sectors are the factors of accessibility, and mode of transportation.

3. Accessibility

The increased of the fisheries activities will increasingly require good accessibility conditions. With good accessibility will facilitate the distribution of products.

4. Mode of transportation

The increased of fisheries activities will also increase the activity of distribution of products, and will affect the types of modes of transport used.

\section{Development Concept with Minapolitan in East Balikpapan}

Minapolitan region is an area that is growing because of the passage of fishing activities from upstream, processing, to downstream. For development concept in East Balikpapan through Minapolitan approach can be described from upstream to 
downstream subsystem. To compose this concept is carried out in accordance with the results obtained in previous analyzes.

1. The development concept of upstream subsystem

The development concept of upstream subsystem is the concept that supports the increased production of leading commodities. The concept of increased production, can be done through:

a. Improved the quality of human resources by providing socialization or counseling related fisheries techniques to increase production.

b. Counseling and training related to the knowledge and introducing technology to increase productivities.

c. There needs to be support from the government in terms of provision of infrastructure and facilities fisheries to increase production.

2. The development concept of processing subsystem

The development concept of processing subsystems needed to provide valueadded fishery products and value-added for the study area. The concept of processing subsystem, among other things:

a. Improved the quality of human resources in the processing of the leading commodities.

b. Increased product diversification of leading commodities.

3. The development concept of the downstream subsystem

Making the leading commodity as typical products in the area of research through culinary tours and souvenirs.

4. The development concept of supporting subsystem

a. Capital

- The provision of capital to fishermen

- The provision of capital for the development of fish processing industry household scale.

b. Accessibility

Improving the quality of the road, so as to facilitate distribution of the product

\section{CONCLUSIONS}

1. Based on the calculation of growth and share, it is known that the East Balikpapan has a leading commodity, potentially, dominant and static. Leading commodity could be used as a typical commodity for culinary tourism. In addition, to increase the value-added products of fish need processing. Processing activities that can be done is by drying or salting, and fish processing became abon, amplang/crackers into a typical by product of Balikpapan.

2. Based on the results of correlation and regression analysis, the factors that influence the development Minapolitan in East Balikpapan include fishermen income; linkages between sectors; the production of fisheries; capital; mode of transport; and accessibility.

3. The development concept that can be done in the area of research starting from upstream subsystem, processing subsystem, downstream subsystem, and supporting subsystem. 


\section{REFERENCES}

Adnan (2010), Analisis Suhu Permukaan Laut dan Klorofil-A Data Inderaja Hubungannya dengan Hasil Tangkapan Ikan Tongkol (Euthynnus Affinis) di Perairan Kalimantan Timur, Amanisal, 1(1), 1 - 12. FPIK Unpatti, Ambon.

Anonim (2011), Keputusan Menteri Kelautan dan Perikanan Republik Indonesia Nomor 18 Tahun 2011 Tentang Pedoman Umum Minapolitan, Kementrian Kelautan dan Perikanan Republik Indonesia, Jakarta.

Anonim (2011), <http://www.balikpapanpos.co.id/index.php?mib=berita.detail\&id $=98147>($ Accessed on 10 March 2014).

Anonim () <http://www.bappenas.go.id $>$ (Accessed on 10 March 2014).

Arikunto, S. (1998), Prosedur Penelitian: Suatu Pendekatan dan Praktek, Reka Cipta, Jakarta.

Arnawa, I K. and Arisena, G. M. K. (2013), Potensi Daya Dukung Pengembangan Kawasan Minapolitan di Kabupaten Gianyar, Bali, Agriekonomika, Oktober 2013, Universitas Mahasaraswati, Denpasar.

Badan Pusat Statistik Kota Balikpapan (2013), Kota Balikpapan Dalam Angka 2012. BPS Kota Balikpapan, Balikpapan.

Dahuri, R., Rais, J., Ginting, S. P., and Sitepu, M. J. (2001), Pengelolaan Sumberdaya Wilayah Pesisir dan Lautan Secara Terpadu, Jakarta.

Effendi, I. (2006), Manajemen Agribisnis Perikanan, Penebar Swadaya, Jakarta.

Friedman, J and Douglas, M. (1976), Agropolitan Development: Towards a New Strategy for Reginal Planning in Asia.

Ghufron, M. (2008), Budidaya Perairan, PT Citra Aditya Bakti, Bandung.

Hoover, E. M. (1977), Pengantar Ekonomi Regional (Terjemahan A. Chandra), Lembaga Penerbit FE UI, Jakarta

Irawan, A. and Sari, L. I. (2006), Karakteristik Distribusi Horizontal Parameter Fisika-Kimia Perairan Permukaan di Pesisir Bagian Timur Balikpapan, Ilmu Perikanan Tropis, 18(2), Universitas Mulawarman, Samarinda.

Mulyadi (2005), Ekonomi Kelautan. PT Raja Grafindo Persada, Jakarta.

Razi, F. (2012), <http://komunitaspenyuluhperikanan.blogspot.com /2012/06/potensi-perikanan-kota-balikpapan.html> (Accessed on 25 November 2013)

Sarwono, J. (2006), Analisis Data Menggunakan SPSS, Andi, Yogyakarta.

Suharto, R. B. (2012), Keuntungan Maksimum Usaha Nelaya di Kecamatan Balikpapan Timur, Forum Ekonomi, 15(2), Samarinda.

Sulaiman, W. (2004), Analisis Regresi Menggunakan SPSS, Contoh Kasus dan Pemecahannya, Andi, Yogyakarta.

Sunoto, Arah Kebijakan Pengembangan Konsep Minapolitan di Indonesia.

Yamin, S. (2011), Regresi dan Korelasi dalam Genggaman Anda, Salemba empat, Jakarta.

Zakiyah, D. M. (2011), Arahan Pengembangan Sektor Perikanan Berbasis Minapolitan (Studi Kasus: Perikanan Tambak Kecamatan Ujungpangkah Kabupaten Gresik). Final Report: Fakultas Teknik. Universitas Brawijaya, Malang. 